\title{
Usługi finansowe w dobie cyfryzacji - aspekty prawne a tendencje docjodemograficzne
}

\author{
Financial services in the digital age - legal aspects \\ and social-demographic trends
} mgr Agnieszka Wachnicka

E-mail: wachnicka.agnieszka@gmail.com

\begin{abstract}
Streszczenie
Postęp technologiczny oraz zmiany socjodemograficzne prowadzą do istotnego przemodelowania krajobrazu na rynku finansowym. Artykuł przedstawia problematykę uwarunkowań socjodemograficznych i technologicznych w aspekcie szans i wyzwań dla instytucji finansowych oraz analizuje aspekty prawne technologicznych przemian na rynku finansowym z punktu widzenia zarówno podmiotów na nim funkcjonujących, jak i konsumentów usług finansowych.
\end{abstract}

Słowa kluczowe: fintech, techfin, pokolenie Y, pokolenie Z, cyberbezpieczeństwo

\section{Summary}

Technological progress and social-demographic changes lead to substantial reshaping of the financial market. The article presents social-demographic and technological conditions in terms of opportunities and challenges facing the financial market. Furthermore the article analyses legal aspects of the technological changes on the financial market, both in terms of the entities functioning on the market as well as of the consumers of the financial services.

Key words: fintech, techfin, generation Y, generation Z, cybersecurity

JEL: G20, K22

Str. $9-15$

\section{Bibliografia}

\section{Literatura}

Arjunwadkar P. (2018). FinTech: The Technology Driving Disruption in the Financial Services Industry. London: Boca Raton.

Bank of International Settlements. (2018). Implications of fintech developments for banks and bank supervisors. Basel: Bank for International Settlements. https://www.bis.org/bcbs/publ/d431.pdf (04.02.2019 r.).

EY. (2017). Shifting into high gear: mitigating risks and demonstrating returns. Global Forensic Data Analytics Survey 2016. https://www.ey.com/gl/en/services/assurance/fraud-investigation---dispute-services/ey-shifting-into-high-gear-mitigatingrisks-and-demonstrating- returns (04.02.2019).

Financial Stability Board. (2017). Financial Stability Implications from FinTech. Supervisory and Regulatory Issues that Merit Authorities' Atten- tion. Basel: Financial Stability Board. http:http://www.fsb.org/wp-content/uploads/R270617.pdf (04.02.2019).

GUS. (2019). Społeczeństwo informacyjne w Polsce — materiały z lat 2006-2018 oraz Polska w liczbach — za lata 2017-2018, http://stat.gov.pl (04.02.2019).

Hysa B. (2016). Zarządzanie różnorodnością pokoleniową. Zeszyty Naukowe Politechniki Śląskiej. Organizacja i Zarządzanie, (97), 385-398.

Kisiel P. (2016). Millennialsi — nowy uczestnik życia społecznego? Studia Socialia Cracoviensia, 14(1), 83-94.

Komisja Europejska. (2018). Komunikat Komisji do Parlamentu Europejskiego, Rady, Europejskiego Banku Centralnego, Europejskiego Komitetu Ekonomiczno-Społecznego I Komitetu Regionów Plan działania w zakresie technologii finansowej: w kierunku bardziej konkurencyjnego i innowacyjnego europejskiego sektora finansowego COM (2018) 
109/F1. Bruksela: Komisja Europejska.

Krajowy Rejestr Długów. (2018). Pokolenie Y - (nie) dorośli do długów. https://krd.pl/Centrum-prasowe/Informacjeprasowe/2018/Pokolenie- Y---(nie)-dorosli-do-dlugow (07.02.2019).

PBS (2016). Czy wystarczająco uważnie podpisujemy umowy i czy dziennikarze pomagają w edukacji konsumentów?, Warszawa: PBS. http://pres- sclub.pl/wp-content/uploads/2016/11/Jak-Polacy-zawieraj\%C4\%85-umowy-i-rola-dziennikarstwaekonomicznego. pdf (07.02.2019).

PwC (2018). Cyber-ruletka po polsku. Dlaczego firmy w walce z cyberprzestępcami liczą na szczęście. Warszawa: PwC, https://www.pwc.pl/pl/pdf/publikacje/2018/cyber-ruletka-po-polsku-raport-pwc-gsiss-2018.pdf (04.02.2019).

Ratajczyk M. (2017). Jak kupuje generacja Y? Studia Ekonomiczne. Zeszyty Naukowe Uniwersytetu Ekonomicznego w Katowicach, (330), 184-193.

Rozkrut D. (2017). Zjawiska i procesy kształtujące rozwój społeczeństwa informacyjnego i gospodarki cyfrowej w Polsce. W: K. Flaga-Gieruszyńska, J. Gołaczyński, D. Szostek (red.), E-obywatel. E-sprawiedliwość. E-usługi (3-14), Warszawa: C.H. Beck.

Rzecznik Finansowy. (2018). Raport Rzecznika Finansowego: Problemy klientów na „rynku Forex”. Warszawa: Rzecznik Finansowy. https://rf.gov.pl/pdf/Raport_Forex_RF.pdf (07.02.2019).

Swacha-Lech M. (2017). Oczekiwania millenialsów w zakresie usług finansowych, Zeszyty Naukowe Wyższej Szkoły Bankowej w Poznaniu, 73 (2), 167-179.

Szpringer W. (2017). Nowe technologie a sektor finansowy. FinTech jako szansa i zagrożenie. Warszawa: Poltext.

Związek Banków Polskich. (2019). Raporty NetB@nk. Bankowość internetowa i płatności bezgotówkowe. IV kwartał 2010 r. — III kwartał 2018. Warszawa: Związek Banków Polskich. https://zbp.pl/raporty/raport-netb-nk (04.02.2019).

\section{Źródla internetowe}

https://en.oxforddictionaries.com/definition/fintech (04.02.2019)

https://www.fintechweekly.com/fintech-definition (04.02.2019)

https://www.investopedia.com/terms/f/fintech.asp (04.02.2019)

\section{Akty prawne}

Dyrektywa Parlamentu Europejskiego i Rady (UE) 2015/2366 z 15.11.2015 r. sprawie usług płatniczych w ramach rynku wewnętrznego, zmienia- jąca dyrektywy 2002/65/WE, 2009/110/WE, 2013/36/UE i rozporządzenie (UE) nr 1093/2010 oraz uchylająca dyrektywę 2007/64/WE (Dz. Urz. UE L 337, s. 35).

MIFiD 2014 - Dyrektywa Parlamentu Europejskiego i Rady (UE) 2014/65/UE z 15.05.2014 r. w sprawie rynków instrumentów finansowych oraz zmieniająca dyrektywę 2002/92/WE i dyrektywę 2011/61/UE

Dyrektywa Parlamentu Europejskiego i Rady 2008/48/WE z 23.04.2008 r. w sprawie umów o kredyt konsumencki oraz uchylająca dyrektywę Ra- dy 87/102/EWG (Dz. Urz. UE L 133, s. 66).

Rozporządzenie delegowane Komisji (UE) 2018/389 z 27.11.2017 r. uzupełniające dyrektywę Parlamentu Europejskiego i Rady (UE) 2015/2366 w odniesieniu do regulacyjnych standardów technicznych dotyczących silnego uwierzytelniania klienta i wspólnych i bezpiecznych otwartych standardów komunikacji (Dz. Urz. UE L 69, s. 23).

Ustawa z 19.08.2011 r. o usługach płatniczych (Dz. U. z 2019 r. poz. 659). 